\title{
Editorial
}

\section{Summary of the Joint European Association of Pediatric Surgeons (XIII) and British Association of Paediatric Surgeons (LIX) Congress in Rome, June 13-16, 2012*}

\author{
Mark Davenport ${ }^{1}$ Benno Ure ${ }^{2}$ \\ ${ }^{1}$ Department of Paediatric Surgery, King's College Hospital, London, \\ United Kingdom \\ 2 Department of Paediatric Surgery, University of Hannover, Hannover, \\ Germany
}

Eur J Pediatr Surg 2013;23:1-2.

Mille viae ducunt homines per saecula Romam ["A thousand roads lead men forever to Rome] was the call of the mediaeval pilgrim and so paediatric surgeons from around the globe travelled to the second of their joint European congresses. The setting was the glitteringly modernist Auditorium Parco della Musica in the verdant surrounding of the old Olympic park.

The meeting attracted 1094 abstract submissions, the highest for this congress, and of these, 131 were accepted and presented as oral papers and 296 as posters. There were 886 delegates registered with 32 commercial sponsors and 19 exhibitions.

The scientific highlight of the meeting was the fiercely competitive Young Investigator/Peter Paul Rickham session (12 submissions), whereby a not inconsiderable prize was awarded to the best presentation of original work. Remember, this may have been the culmination of a young trainee's research career; all were sure-footed and slick in presentation, and sparkled with energy and originality. The winning presentation was entitled "Interleukin-17 (IL-17) producing lymphocytes initiate the inflammatory destruction of bile ducts in experimental biliary atresia" by Christian Klemann from Hannover, Germany. The other awards were based on poster presentations and judged by the plebeian element of the audience.

There were several invited guest lectures in the congressall from Europe this year. Michael Hollwarth from Graz gave the Duhamel Lecture; Jeff Valla from Nice entertained in the Karl Storz Lecture; and Benno Ure, in the European Lecture, mused sagaciously on the development of laparoscopic surgery for children. The non-arrival of the Journal of Pediatric Surgery lecturer deepened a few facial worry lines in the faces of the BAPS organising committee. However, the story had a

*The article has been jointly published in the Congress editions of the Journal of Pediatric Surgery and the European Journal of Pediatric Surgery.

more than happy ending as Paolo De Coppi (expatriate Italian, but working in London) delivered a cool, impassioned resume of all things stem-cell and regenerative. An obvious case of a substitute being brought on in the last five minutes of a game and scoring the winning goal.

There were two awards of societal medals this year. The recipient of the Denis Browne Medal for 2012 was Adrian Bianchi from Manchester. This, in our view, was long overdue and he has acted as a maverick but influential figure for many of the younger generation of UK and European surgeons. Not many surgeons can claim to name original operations but Adrian has a legally binding case for at least two and arguably three. The Rehbein Medallist this year was another giant in many fields, Prem Puri from Dublin. Again, he has an excellent claim to original procedures such as the Sting technique for vesicoureteric reflux. He is also highly influential as the editor of a major pediatric surgical journal and several authoritative textbooks while almost single-handedly upholding basic science research in Ireland.

The "Meet the Expert" lunches were over-subscribed as usual and are destined to be permanent fixtures in the congress calendar. Among the distinguished contributors, Dan Teitelbaum, Jean-Michel Triglia, Sebastian Van As, Paul Tam, and Steven Stylianos all gave as good as they got.

There were several sideshows before the main event main congress itself with well-attended courses in both laparoscopy and oncology, and History and Experimental Research Clubs. Simon Eaton's erudite review of "Meta-analysis" from the latter is published in the Journal of Pediatric Surgery.

Presenters who wanted to see their work in print have had two choices this year with submissions to either the Journal of Pediatric Surgery (JPS) or the European Journal of Pediatric Surgery (EJPS).

33 manuscripts were submitted to the EJPS and reviewed by the EJPS publication committee consisting of Whit

(c) 2013 Georg Thieme Verlag KG Stuttgart · New York
DOI http://dx.doi.org/ $10.1055 / \mathrm{s}-0033-1334869$. ISSN 0939-7248.

Address for correspondence

Davenport, King's College

Hospital, Denmark Hill, London

SE5 9RH, United Kingdom

(e-mail: Markdav2@ntlworld.

com). 
Holcomb, Agostino Pierro, Holger Till, Juan Tovar, and Tomas Wester. The committee accepted 15 excellent manuscripts for publication mainly dealing with clinical aspects of pediatric surgery. 63 manuscripts were submitted to the JPS publications committee who scrutinized long and hard to select out this year's pick of 22 full papers and two reviews and my thanks goes to Ian Sugarman, Kokila Lakhoo, Majella McCullagh, Paul Losty, and Paul Johnson, with indefatigable coaching from Jay Grosfeld.

Outside of the conference, Rome beckoned and beguiled. The president's reception was held in the back garden of the 19th century Palazzo Brancaccio. This was set amongst fauxruined columns, vine-clad pergolas, and burbling fountains; and then through the main portico into a series of chandeliered rooms lined with gilt-framed mirrors. The formal annual dinner similarly could not have been situated better; a short walk up the Capitoline Hill-one of the seven sacred hills of ancient Rome-with views over the Forum and its ruined basilicas, temples, and archways, to the Piazzale Cafferelli. There on the Terrazza, assembled diners looked out over the sun setting behind the dome of St Peter's and the Vatican skyline, and right bank of the Tiber to the sublime strains of a string quartet playing gentle Mozartian melodies.

The roads will divide next year and BAPS is off to the Dorset seaside of Bournemouth on England's south coast. We look forward to fish and chips served in yesterday's newspaper and the vagaries of an English summer. EUPSA, by contrast, heads across the Alps and turns to Germany and the glorious Saxon city of Leipzig where Wagner was born, J.S. Bach played the organ, and Felix Mendelsohn, Gustav Mahler, and Robert Schumann conducted the local orchestra. So, the choice is yours. 